\title{
特集【論説】 紛争・訴訟問題からみたまちづくり手法の有効性と限界
}

\section{総合設計をめぐる紛争と制度的解決に向けての考察}

Troubles over the buildings of the integrated designed system and a study of institutional prevention of the troubles.

Yu TOMITA : lawyer at Kagurazaka law firm office

富田＼cjkstart裕*

\section{1 建築紛争を誘発する総合設計}

総合設計の制度は, もともと, 市街地には建物 が密集し，公共的な空間にそしいことから，建築 物の周囲に一定の公開空地を確保するという目的 で1970年に創設された制度である。総合設計制度 は，一定の公開空地を設けることで市街地環境の 整備改善が認められる場合, 計画建物の容積率, 高さ制限, 斜線制限の緩和をボーナスとして認め, 大規模かつ高層の建築を可能としている（建築基 準法59条の 2 )。※1

この制度を利用すると, 周辺が低層住宅の地域 であっても，局所的に周囲と隔絶した超高層建築 物を建てることが可能となり, 周辺環境に断絶を 生じさせることとなる。これにより，高層建築物 の周辺の住宅地には景観, 風害, 圧迫感等の環境 悪化（経済学でいう外部不経済）が生じるため, 周辺住民が反対，建築紛争を引き起こしている例 がある。

建物が建築されるに際し建築主と周辺住民との間 で紛争が起こった建築紛争事例を見ると, ただ単 に住民の景観に対する意識が高まってきたから紛 争が増えたというよりも, 建築紛争を誘発させる 制度改正や制度運用が原因となって紛争が増えた と見ることが可能な場合が多い。
たとえば地下居室の容積率不算入という制度改 正の結果, 斜面地マンションが多数建設されるこ とになり建築紛争が増えた例, 天空率制度の導入 により斜線制限が緩和された結果として超高層建 築が可能となり建築紛争が増えた例は, 制度改正 が発端となって良好な環境の地域に環境の悪化 (経済学でいう外部不経済)を発生させ, 建築紛争 を誘発した例である。

近年の総合設計制度の運用による建築紛争も建 築規制の緩和が周辺環境との隔絶を発生させて建 築紛争を誘発したという点で, これらの制度改正 による建築紛争と共通していると見ることができ る。

実際，2003〜2007年までの 5 年間，東京都の建 築審査会に対してなされた大規模建築物（延べ床 面積 1 万 $\mathrm{m}^{2}$ 以上）に係る審査請求の件数を見ると, 総合設計を除く大規模建築物 1,261 件あるうち, 審 査請求を受けたものは37件であるから, 審査請求 率は $2.9 \%$ にすぎない。

これに対し，総合設計による大規模建築物 135 件のうち, 審査請求を受けたのは 11 件で, $8.1 \%$ も ある。

このことは, 総合設計による大規模建築物が一 般の大規模建築物と比べ, 約 2.8 倍, 審査請求を受 けやすいことを意味する。※2 
一般の大規模建築物と比して, 総合設計による 大規模建築物が審査請求を受けやすい理由は, 総 合設計が，もともとの用途地域が定めている高さ 制限や容積率制限を緩和して, 周辺の建物と隔絶 した規模の建物を可能とするため, 周辺環境に与 える悪影響が大きいことによると考えられる。

\section{2 紛争原因の考察}

\section{（1）規制緩和による市場の失敗の再現が建築紛争 を誘発}

所有物に対する個人の自由な権利からすれば, 土地所有者は, 自分の所有する土地にどのような 建築物を建てることも自由である。この建前から， 建築基準法も建築の自由を原則とし,「最低限の基 準」（建築基準法 1 条）として定められている。

しかし, 土地所有者が周辺環境から突出した建築 物を自由に建築すると, 局所的に市街地環境に断 絶が生じ, 当該建築物により周辺の環境が悪化す る。これを外部不経済と言い, 個々人の自由に委 ねると最適な資源配分とならない市場の失敗の一 例とされる。

そこで，公共部門による市場介入が必要となり， 都市計画法, 建築基準法は, 用途地域を定め, 用 途地域に応じた容積率, 高さ規制, 日影規制等を 行っている。

例えば，東京都の「用途地域等に関する指定方 針及び指定基準」では, 「用途地域の変更及び決定 にあたって留意すべき事項」として, 用途地域の 指定に関し,「住居系用途地域」と「商業地域, 工 業地域, 工業専用地域」とで, 原則として互いに 接して指定しないことを定めている。

また, 同基準は, 住居系用途地域と商業系用途 地域が隣接する場合において, 隣接する用途地域 相互の容積率の差が過大とならないよう配慮して
設定すること等を定めている。

これらは, 段階的な用途地域の定めと呼ぶこと も可能である。

これに対し, 総合設計制度は, 公開空地の設置 等を条件に, 段階的用途地域の定めに反し, 容積 率規制，高さ規制等の緩和を行うものである。

この制度を利用することで局所的に段階的用途地 域の定めが断絶され，極端に異なった高さ制限の 用途地域が隣接する用途地域の穴抜き状況を作る ことになる。

これは, 当初, 建築自由の原則による市場の失 敗に対応し，公共部門の介入により環境の悪化を 防いでいたのを, 再度, 規制を緩めて一部建築自 由の状況に戻すことを意味する。

とすると, 再度, 市場の失敗と同じ状況が生ま れ, 周辺環境悪化, 外部不経済が生ずることにも なる。

そして, この外部不経済が, 建築紛争を誘発す る。

このように, 総合設計制度は, 制度内在的に建 築紛争を誘発する。

\section{（2）市場の失敗が生じないための制度的担保の機 能不全状況}

ただ,このようなことは総合設計制度を作った 時点から立法者において当然想定されており, そ うであるからこそ, 総合設計制度においては, 外 部不経済が生じないための制度的担保がなされて いる。

その制度的担保とは, 総合設計制度が特例許可 制度として, 市街地環境の改善があるか否かを実 質的観点から十分考慮し, 問題がない場合に初め て許可をする制度であるということである。

しかし, この制度的担保は, 実際には機能して いない。

※2「総合設計制度における高さに起因する紛争の抑制に関する研究 東京都区部を事例に」2008年度日本建築学会関東支部 研究報告集 河村茂 
そして, 制度的担保が機能していないからこそ 市場の失敗が再現し, 建築紛争が起こる原因と なっている。

以下, いかにして, 制度的担保が機能不全に陥っ ているかを見る。

\section{ア 市街地環境の改善に資するかの実質的総合}

\section{判断を求める総合設計制度}

総合設計許可の制度は，具体的な建築計画が市 街地環境の整備改善に資するか否かを総合考慮し た結果, 市街地環境の整備改善に資すると判断さ れて初めて許可を与えるという裁量に基づく特例 許可の制度である。

このような総合設計制度の趣旨からすれば，処 分庁が総合設計制度を具体的建築計画に適用する に当たっては, その計画が市街地環境にとってプ ラスになる側面，マイナスになる側面をそれぞれ 十分に考慮し，プラス面がマイナス面を上回って いるときに初めて許可を与えることになる。

建築基準法59条の 2 は, 総合設計による建築計 画を認める総合設計許可に関し,「政令で定める空 地」(公開空地) を有することを前提に,「特定行政 庁が交通上, 安全上, 防火上及び衛生上支障がな く, かつ, その建ぺい率, 容積率及び各部分の高 さについて総合的な配慮がなされていることによ り市街地の環境の整備改善に資すると認めて許 可」と規定している。

これは, 公開空地による周辺環境へのプラスの 影響が, 容積率緩和, 高さ制限緩和による周辺環 境へのマイナスの影響を上回る時にはじめて許可 を与える趣旨であると解される。

このような周辺環境へのマイナス影響の実質的 判断がなされているなら, 外部不経済の再現や, 建築紛争の発生を防げるはずである。

\section{1 建前上, 実質的裁量判断を行う制度}

東京都においては, 建築基準法59条の 2 による 総合設計許可の取扱方針として, 東京都総合設計 許可要綱（以下，「許可要綱」という。）によるこ
ととされている。

許可要綱では, 第 1,5 以降で適用の要件（数 值基準）が詳細に示されているが，その前の第 1,3 の「運用指針」では, 以下の記載がされて いる。

「この基準は, 技術基準として, 許可の申請に当 たっての必要条件としての性格を持つものであり, 許可の条件を十分に満たすものであるか否かは, 具体的な計画に即し, 総合設計制度の趣旨等を勘 案して判断する必要がある。したがって, 本制度 の運用に当たっては, 常に趣旨及び基本目標に照 らして総合的見地から行うものとする。」

このように許可要綱では, 総合設計許可を行う に当たっての必要条件, 十分条件という二つの条 件をあげ，許可を与えるには，両者を満たす必要 があるとしている。

必要条件とは, 数值基準たる技術基準に適合し ていることである。

この基準は数值基準であり, 定められた数值に 適合しているかのみが審査される裁量のない覊束 行為である。この数值基準には周辺環境の評価は 入っていない。

そして, 敷地規模さえ満たせば最も規制の厳し い第一種低層住居専用地域を含め, どの場所でも 総合設計で建築できることになっている。

十分条件とは, 数值基準を充たしていることを 前提に, 行政庁が個別具体的に市街地環境の改善 となるかを裁量判断するということである。

総合設計制度の利用は, 公開空地による敷地周 辺環境へのプラスの影響が, 容積率緩和, 高さ制 限緩和による周辺環境へのマイナスの影響を上回 ることを前提としているから，十分条件としては， この点の審査を具体的事例ごとに裁量判断するこ とになる。

そうすると, 許可要綱は, 数值基準を満たすこ 
とを必要条件に, さらに, 当該建築計画が市街地 環境の改善となるか否かを個別具体的に裁量判断 するという十分条件の部分の検討を経て, 許可を 行う二段階の構造である。

そうすると, 総合設計許可においては, 十分条 件として周辺環境へのマイナス影響の実質的判断 がなされるから, 外部不経済の再現や建築紛争の 発生を防げるはずである。

\section{ウ 実際は建築確認と同じく，数値基準を満た} せば，即許可

しかし，実際の総合設計許可要綱の運用を見て いると, 数值基準に適合している限り，そのまま 許可を与えるという形で, 数值基準適合性だけが 審査対象となっている。

総合設計許可に不可欠な周辺環境の総合判断は, 行われていない。

この意味で，総合設計許可は，実際の運用とし ては，建築確認と同じである。

すなわち, 数值基準に適合している限りにおい て許可が与えられる裁量のない覊束行為である。

このように, 数值基準だけの審査で終わり周辺 環境の総合評価に基づく裁量判断が行われないか ら，建築紛争が多発することになる。

総合設計許可が，周辺環境に対する総合評価や 裁量判断を伴わない制度運用となっているため, 建築紛争となった例として, 以下, 筆者も代理人 となった（仮称）西浅草 3 丁目計画の総合設計許 可の事例（浅草寺景観訴訟の事例）をあげる。

\section{工 浅草寺景観訴訟に見られる確認的運用}

(仮称) 西浅草 3 丁目計画は, 西浅草 3 丁目に図 1 のような高さ $130 \mathrm{~m}$, 階数 37 階を越える高層建築 を建てる計画である（図 1 ）。

この計画に関し, 周辺住民及び浅草寺が, 総合 設計許可取消を求めて提訴した。

原告らは, この (仮称) 西浅草 3 丁目計画が台 東区都市計画マスタープランに反することを理由 に，総合設計許可の違法を主張した。

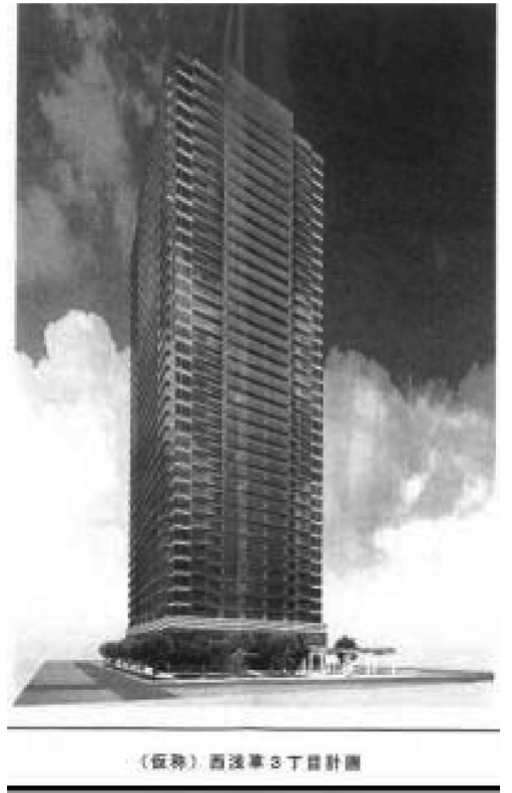

図 1 (仮称) 西浅草 3 丁目計画

台東区マスタープランには，土地利用方針図が ある。土地利用方針図の中で, 建物の計画されて いる西浅草 3 丁目地域は, 「中・低層地（概ね 3 5 階程度)」と記載されている。実際, 計画地の周 辺は, $2 \sim 3$ 階建て程度の建物が大部分を占めて いる。

そして, 台東区マスタープランは「中・低層地 (概ね $3 \sim 5$ 階程度)」の記載の趣旨について, 以 下のように述べている。

「集合住宅の建設は, 下町情緒が残る街並みや家 並み, 商店街といったまちの連続性, 景観・日照 等の住環境に影響を与えていると懸念されている。 こうしたことから，地域の特性にあわせた地域レ ベルでの土地利用誘導方策の検討を行い, 下町に ふさわしい住環境の形成を進めていくことが必要 となっている。」

すなわち, 台東区マスタープランは, 集合住宅 


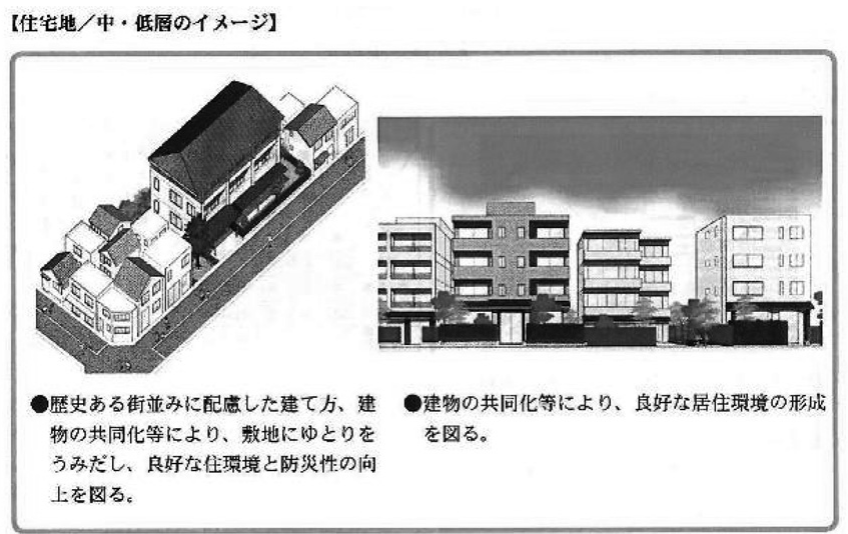

図 2 中・低層のイメージ

の建設による街並みの連続性，景観・日照等への 悪影響を懸念し, 下町にふさわしい住環境の形成 をするため,「中・低層地（概ね $3 \sim 5$ 階程度）」 と定めた。

そして，この「中・低層」という建物の高さに 関しては, 台東区都市計画マスタープランの図に おいて, 図 2 の低層, 中層の 4 階建て程度の建物 のイメージが示されている。

図 1 の (仮称) 西浅草 3 丁目計画は, 図 2 の 4 階程度の階数のビルと比較し, 37階 + 塔屋 2 階と, マスタープランの目標からすると, 実に 9 倍以上 もの階数を有する。

そこで, 原告らは, 本件建築計画は, 台東区マ スタープランの「中・低層地（概ね $3 \sim 5$ 階建て 程度)」に反するから, 本件総合設計許可は違法で あると主張した。

東京地方裁判所平成22年10月15日判決は, 「台東 区マスタープランは「基本的な方針」とされ，基 本理念であり目標とされているにすぎず，…そう であるとすると， 3 ないし 5 階以外の建物以外の 存在を許容しない趣旨とは到底考えられない。」と した。

本来, 総合設計制度が周辺環境を考慮して市街 地環境の改善に資するかの実質的判断のもとに特
例許可を与える制度であるならば，行政庁は（仮 称）西浅草 3 丁目計画の許可に際し, 当該計画が, 台東区マスタープランに適合するか否かの判断を 実質的に行う必要があったはずである。

しかし, 東京都は, 要綱記載の数值基準適合性 の判断のみを行い, 当該建築計画がマスタープラ ンに適合するか否かの実質的判断はしないまま, 許可した。

そして, 裁判所も, この判断を是認した。

(仮称) 西浅草 3 丁目計画の総合設計許可は, 数 值基準を満たしている限りにおいて許可する総合 設計許可制度の確認的運用の典型例といってよい。 そして, 周辺環境の評価なしに許可したからこ そ, 外部不経済が再現し, 建築紛争となった。

\section{3 解決可能性についての考察}

\section{（1）私人間の契約（コースの定理）による解決は} 困難

では，このような建築紛争が起こらないように するには,どうすればよいか。

紛争を解決方法として, 一つには, 事業者側と 住民側との合意により外部不経済が生じない状況 を作ることが考えられる。いわゆる, 経済学でい うコースの定理による外部不経済解消である。 
コースの定理についてここで説明する紙幅はな いが，コースの定理は，私人間の自由な契約によ り，一方が他方に補償金を支払うことで外部不経 済が解消し，最適な資源配分を実現できるとする。

そして, コースの定理が機能し, 最適な資源配 分を実現できるためには，(1)権利関係が明確であ ること一具体的には, 污染者側と被害者側とで, 污染者側に污染する権利が与えられているのか, 被害者側で污染させない権利があるのかが明確に 定まっていること, (2)両者の取引費用がゼロない しは無視できるほど小さいこと, が必要であると されている。

では, 総合設計をめぐる建築紛争でコースの定 理が機能するか。

ここでは，住民と事業者側との交渉，取引で, どの程度のヴオリュームを建てるかを決すること になる。この場合, 土地所有権を有する事業者側 に建築自由の原則が認められるから, 事業者側に 建てる権利がある（この点, 鉄道による騒音が住 民に受忍限度を超える被害を与えれば不法行為を 形成し, 被害者側に騒音を受忍しない権利がある と判断されるのと異なる。）。

そこで，住民側が補償金を支払うことを事業者 側に持ちかけ, 当初予定よりも建物のヴォリュー ムを小さくする契約締結を持ちかけることになる。 ここで，住民側は，契約を持ちかけるに当たって 大きな問題に直面する。

住民の受ける環境上の不利益は, 日影, 景観, 圧迫感，風害など金銭的に評価できないものであ る。高層ビルが建ったからといって隣地住民が病 気になるわけでもなく, 治療費が必要となるもの でもない。

実際には，環境上の不利益を金銭に見積もるこ とはできないし，実際以上に低く評価される。

これに対し，事業者が受ける利益は莫大であり， 金銭的に評価可能である。

そうすると, 財力にも限界がある住民側が, 金
銭に見積もれない環境上の不利益が発生しないた めに補償金を支払って事業者側の建築中止を求め るにも，住民側には補償金を支払うこともできず， 交渉は成立しない。

結局, 個別契約の集積が市場であるところ, 市 場のもとで外部化されている環境利益を, 個別の 契約において内部化することは困難である。

そうすると, 契約（コースの定理）により住民 側が補償金を支払い, 建物の高さを制限させると いうことは，実際は実現し難く，住民は，総合設 計による高層建物による環境悪化を甘受するしか ない。

\section{（2）制度改正による解決の可能性}

\section{ア 許可に当たって, 敷地外の周辺環境, 場所} の特性をいかに評価するか

総合設計制度運用における紛争の原因は, 規制 緩和により市場の失敗が再現され，外部不経済が 再度発生することにあった。

そうすると，規制緩和するにしても，政府の介 入を残しつつ, 外部不経済の発生しない方法での 緩和をできないか。

総合設計制度運用において近隣紛争が生じる大 きな原因は，その制度が段階的な用途地域の定め に断絶をもたらし, 都市計画の穴抜き状況を作る ことであった。

この穴抜き状況は, 総合設計制度が, 敷地外の 立地条件を全く考慮せずに，敷地内だけで数值基 準を満たしている限りにおいて許可を与える制度 になっていることから引き起こされている。

そうだとすると, 総合設計許可制度の運用にお いて, 敷地外立地条件をいかに評価し, 総合設計 制度の運用に結びつけるかが大切となる。

敷地外の立地条件, 周辺環境を許可制度の中で どのように評価するかは, 様々な方法が考えられ る。

ここでは, (1)運用の可否という入口の局面にお ける周辺環境評価, (2) 数值基準設定における周辺 
環境評価, (3)実質的裁量判断における周辺環境評 価の 3 点について考えてみる。

\section{(1)運用の可否という入口の局面での周辺環}

\section{境評価}

まず，(1)の運用の可否という入口の局面におけ る敷地外の状況の評価である。

現在，東京都23区では，許可要綱上，どのよう な地域でも総合設計制度を使って建築物を建てる ことが可能である。例えば，第一種低層住居専用 地域でも敷地面積 $1000 \mathrm{~m}^{2}$ を満たせば, 総合設計制 度による容積率緩和等を受けることができる。

しかし, 東京でも, 湾岸の埋め立て地帯で将来 に高層ビル群が予定されているところに総合設計 を用いて建築物を建てても環境悪化はさほどでも ないが，既成の住居系の地域で総合設計を用いて 高層ビルを建てると, 周辺環境との明らかな断絶 が生じ，建築紛争が生じる。

そこで，例えば許可要綱を改正し，総合設計制 度の利用をできる地域を限定することが考えられ る。例えば，総合設計制度を利用できる区域を特 区のような形で設定し，どこでも総合設計を利用 できるわけではないことにする。

その際，マスタープランの記載による地域の評 価は，総合設計制度を利用できるか否かの定めを 設けるのに参考となるだろう。

\section{ウ (2)数值基準設定における周辺環境評価}

次に, (2) 数值基準設定における評価であるが, 現状では, 許可要綱上, 数值基準は, 接道長さ, 建ぺい率, 公開空地率など敷地内部の数值基準だ けを要件とし，敷地外部と敷地との関係における 数值基準を全く設けてない。

これを, 許可要綱において周辺の建築物の高さ 調査及び分析を義務づけ, 許可対象建築物と周辺 の建築物の高さとの間に一定の比例を要求すると か, 周囲に高さが一定以上の建物が一定数以上あ る場合に限り許可が可能となるといった基準を設 けることが考えられる。

\section{エ (3)裁量判断における周辺環境評価}

次に, (3)裁量判断における立地条件, 周辺環境 の評価である。

裁量判断に関していうと, 許可に当たっては, 公開空地を設けること等によるメリットと高層建 築による環境悪化のデメリットとを比較し，公開 空地を設けることによるメリットが上回る必要が ある。

ここで,メリットとデメリットを数值化し, 費 用便益分析により，費用よりも便益の方が大きい から許可を与えるという方法をとれるなら，その ような方法をとりたいところである。

しかし，公開空地を設けることによるメリット も, 高層建築による環境悪化のデメリットも, 双 方とも市場で評価不可能な外部効果であり, 数值 化になじまない。

しかも，公開空地を設けることによるメリット と, 環境悪化のデメリットは，それぞれ同じ土俵 で比較できるものではなく，一方が大きいから必 ず他方を犠牲にしても良いというものでもない。 そうすると, 裁量判断に当たっては, いくつかの 項目の定性基準 (考慮事項。例えば, 「周辺環境と 調和した建築スケールに配慮する」とか,「周辺と の連続性に配慮する」「分棟, 分節等によりボユー 么感を軽減し, 周辺景観と調和させる」等の項目) を設け, 項目ごとに定性基準適合性を評価し, 最 終的にそれぞれの定性基準（考慮事項）適合性の 総合評価することで裁量判断を実質化していくし かない。

現状の許可要綱のいう裁量判断が機能しない理 由の一つには, 裁量判断に当たっての定性基準, 考慮事項が何も設定されていないため，何を考慮 して裁量判断したら良いかが不明であり, 結局, 何も裁量判断しないことになっていることがある。 このような現状からすれば, 裁量判断事項につ いて定性基準（考慮事項）を明示することは，一 歩前進である。 


\section{オ 事前明示の要請(取引費用最小化要請) との} 調整

定性基準で，敷地外の条件を記述するにしても， 許可申請者側からすると, 定性基準が具体的で, なるべく事前明示性がある方が好ましい。

この点, 行政手続法 5 条 1 項は, 申請者の利益 に配慮し,「行政庁は, 審査基準を定めるに当たっ ては，許認可等の性質に照らしてできる限り具体 的なものとしなければならない。」と規定している。

これは, コースの定理の含意でもある。すなわ ち，コースの定理は，私人間の契約の自由により， 資源の最適配分をめざすものではあるが，私人と 行政庁との関係も, 結局は私人の権利の実現のた めに行政訴訟を必要とすることからすれば，私人 と行政庁との間にもコースの定理の趣旨は及ぶ。 許可要件の事前明示は，コースの定理のいう取引 費用の最小化の要請でもある。

定性基準を記述するとしても，なるべく具体的 で事前明示性のあるものにして取引費用最小化を 図る必要があるということである。

しかし, 一方で, 敷地と周辺環境との関係から 定性基準を立てるに際し, 周辺環境は, その地域 の歴史, 文化, 敷地の特徴など, 様々な要素を考 慮して設定せざるをえず，予め具体的かつ詳細な 明示的定性基準を立てるのは困難である。定性基 準 (考慮事項) としては, 周辺環境の個別事情を 考慮するために，ある程度抽象的，概括的なもの にしたい要請もある。

そうだとすると, 裁量判断のための考虑事情と して, 取引費用最小のための事前明示の要請と個 別の敷地事情考慮のための概括的, 抽象的記載の 要請とをいかに調整するがが問題となる。

調整として, 一つには, 例えば, 定性基準の内 容として,「周辺環境と調和した建築スケールに配 慮する」とか, 「周辺との連続性に配慮する」「分 棟, 分節等によりボユーム感を軽減し, 周辺景観 と調和させる」等の抽象的文言を立てる方法が考
えられる。

この場合，事前明示性（取引費用最小化）の問 題が生じるのは確かだが, 許可申請に係る事例の 集積により, 漸次, 明示性を高めることで解決を 図る。

もう一つは, ある程度狭い地区単位で個別的に 詳細な定性基準（考慮事情）を立てることが考え られる。例えば, 台東区マスタープランのような 市町村マスタープラン（都市計画法18条の 2 第 1 項）の記載する地区ごとの土地利用の方向性を参 考に, 地区ごとに個別的に詳細な定性基準を作成 することが考えられる。地区単位で個別的に歴史 性や地域性を考慮した詳細な定性基準を作成する ことができれば，事前明示性の問題はある程度解 消する。

\section{カ まとめ}

以上, 建築紛争が発生しないための解決方策に ついて検討したが, 当該建築物が建つ敷地外の周 辺環境の評価を行う場合, 周辺環境 $=$ 場の評価と いう, 当該敷地の歴史, 文化, 敷地状況などの様々 な要素を考慮せざるをえない。

そうだとすると, 数值基準で敷地外の状況を評価 するのでは足りず, 裁量判断において敷地と周辺 環境との関係を評価することは不可欠である。 その際, 事前明示性との関係で問題もあるが, 場 の評価という観点からは, ある程度明示性を犠牲 にしても, 個別具体的な裁量判断を重視し, 明示 性の問題は, 事例の集積で漸次解決を図る配慮も 必要であろう。

*「司法政策の法と経済学」福井秀夫 日本評論社 第11章 権利の配分・裁量の統制とコースの定理

*「景観法制の基準一景観紛争の法と経済分析」 福井秀夫 環境情報科学 35 - 12006

*「景観利益の法と経済分析」福井秀夫 判例タイムズ No1146 (2004. 6. 1) 